\title{
Reproductive biology of Calcinus laevimanus (Randall, 1840) (Decapoda: Anomura: Diogenidae) from Inhaca Island, southern Mozambique
}

\section{Carlos Litulo, Daniela Abreu and Christopher C. Tudge}

\begin{abstract}
Hermit crabs are one of the most abundant taxa in the intertidal habitats of tropical estuarine areas. Despite this situation, many aspects concerning their population ecology and reproduction are still poorly known. In this study, the reproductive biology of the diogenid hermit crab, Calcinus laevimanus was studied with emphasis on size structure, sex ratio, recruitment, breeding season and fecundity. Monthly samplings were conducted between January and December 2003 at Inhaca Island, southern Mozambique. A total of 1966 crabs were collected, represented by 760 males and 1206 females. The size frequency distribution of the present population showed an unimodal pattern skewed to the right, suggesting increased mortality in the largest size classes. Sexual dimorphism was evidenced by the larger sizes attained by males in relation to females. Moreover, sex ratios were femalebiased during most of the study period. Juvenile recruitment was constant with major peaks in March and May, ovigerous females were present year-round peaking February and April and egg number increased with female size. The present results show that reproduction and recruitment of Calcinus laevimanus displays high reproductive activity in the study area, as evidenced by the constant presence of ovigerous females and the high number of eggs carried by females.
\end{abstract}

\section{INTRODUCTION}

Decapod crustaceans represent a large number of living species that inhabit a wide variety of biotopes. Consequently, the study on decapod crustaceans is promising because the establishment of these animals in such diverse habitats derives from the evolution of adaptive population strategies (Mantelatto \& Sousa,
2000). Hermit crabs are anomuran decapod crustaceans that developed some strategies to utilize gastropod shells and other type of cavities to shelter their uncalcified abdomen. According to Litulo (2005), there are currently more than 900 species of hermit crabs worldwide, ranging from the deeper parts of the oceans to intertidal habitats. Despite this situation, the population biology aspects of these organisms are still poorly known, principally in tropical environments.

The large number of studies on hermit crabs mostly focused on behavioural features such as the use of gastropod shells and habitat selection in both the field and laboratory (e.g., Tunberg et al., 1994; Barnes, 1999; Turra \& Leite, 2001a). However, studies on population structure and reproduction of hermit crabs have been conducted for European and Mediterranean (Lancaster, 1988; Manjón-Cabeza \& Garcia Raso, 1994, 1995, 1998), temperate (Asakura \& Kikuchi, 1984; Imazu \& Asakura, 1994), tropical (Kamalaveni, 1949; Ameyaw-Akumfi, 1975; Bertness, 1981) including South American (Fransozo \& Mantelatto, 1998; Mantelatto \& Garcia, 1999; Bertini \& Fransozo, 2002; Martinelli et al., 2002) and African species (Gherardi \& Vannini, 1989; Gherardi et al., 1994; Litulo, 2004; Litulo \& Tudge, 2005).

Breeding periods of hermit crabs have been frequently described and reveal continuous to seasonal patterns (Bertness, 1981; Bertini \& Fransozo, 1999; Turra \& Leite, 2000). Reproductive activity can also be influenced by the adequacy of shells used by the crabs (Bertness, 1981; Mantelatto et al., 2002). Moreover, breeding activity can vary in re- 
sponse to competition for shells in natural habitats (Ameyaw-Akumfi, 1975).

In East African region, studies on hermit crab biology are scarce (e.g., Ameyaw-Akumfi, 1975; Emmerson \& Alexander, 1986; Reddy \& Biseswar, 1993) and, in particular reference to Mozambique, they have been restricted to behaviour and ecology (Barnes, 1997, 1999).

Calcinus laevimanus (Randall, 1840) is one of the most common hermit crabs in the Indo-Pacific region (Gherardi \& Vannini, 1989; Reddy \& Biseswar, 1993; Tudge, 1995a). At both ebb and flood tides, C. laevimanus disperse to feed on the substrate, picking at the detritus-covered rocks and pebbles with its chelipeds (Gherardi \& Vannini, 1989). With the incoming high tide, it retreats into the rocks or pebbles. Often research on this species has been concerned with behaviour (Gherardi \& Vannini, 1989) and patterns of shell utilization (Reddy \& Biseswar, 1993). With the exception of research on spermatozoal and spermatophore ultrastructure (Tudge, 1995b, c), there is no information available on the general reproductive biology of $C$. laevimanus assessed by systematized study performed over a long period. This study addresses the paucity of information and describes the reproductive biology of $C$. laevimanus from Inhaca Island, an estuarine region in southern Mozambique, with emphasis on population size structure, sex ratio, juvenile recruitment, breeding season and fecundity.

\section{MATERIALS AND METHODS}

This study was conducted monthly from January to December 2003 on the full moon, during low tide in the exposed pebble area in front of the Marine Biological Station of Inhaca, Island, southern Mozambique $\left(26^{\circ} 00^{\prime}\right.$ $\left.\mathrm{S}, 33^{\circ} 00^{\prime} \mathrm{E}\right)$. The climate at this location is a mixture of tropical and subtropical, partly influenced by the South-Eastern trade wind, and a northerly monsoon, but also occasionally by strong and cold South-West winds or cyclones from the North-East. The winter (April -September) is usually cold and dry, while summer (October-March) is warm and rainy.
Detailed information on weather conditions as well as detailed descriptions regarding the ecology, fauna and flora of the Island can be found in Guerreiro et al. (1996).

Sampling was performed by two people during a period of 1 hour, covering an area of $300 \mathrm{~m}^{2}$. Almost all hermit crabs were found in small aggregations of 5 or more in small pools that were regularly searched during the study period as reported for Calcinus tibicen in the southern Atlantic (Fransozo \& Mantelatto, 1998). After collection, all individuals were bagged and transported immediately to the laboratory where they were removed by carefully cracking each shell. Sex was determined based on the position of gonopores (coxae of pereiopod 3 for females and pereiopod 5 for males). The cephalothoracic shield length (SL = from the tip of the rostrum to the V-shaped groove at the posterior edge of the carapace) was measured with the aid of Vernier callipers ( $\pm 0.05 \mathrm{~mm}$ accuracy) or under a dissecting microscope equipped with an ocular micrometer. Specimens were grouped in $0.5 \mathrm{~mm}$ size-class intervals, from 2.0 to $10.5 \mathrm{~mm}$.

Ten eggs were removed from each ovigerous female for egg staging. Three stages of embryonic development were microscopically identified based on the amount of yolk and the development of eye pigment (modified from Wada et al., 1995 and Mantelatto \& Garcia, 1999).

Stage I (Initial): light-red, newly deposited eggs completely filled with yolk and no signs of segmentation. Stage II (Intermediate): eggs with less than $80 \%$ of yolk, and the development of zoea observed. Stage III (Final): darkgrey eggs with less than $5 \%$ of yolk and zoea fully developed just a few days from hatching.

Twenty-five ovigerous females with eggs at stage I were selected for egg counting. Pleopods were removed from females, placed in petri dishes filled with seawater, and eggs detached by the gradual addition of a solution of sodium hypochlorite $(7 \%)$. Bare pleopods were then discarded by gently stirring in a beaker filled with $200 \mathrm{ml}$ seawater. Three $1.5 \mathrm{ml}$ subsamples were taken using a pipette, with eggs 
counted under a dissecting microscope. The average value obtained was then extrapolated for the whole suspension to estimate the number of eggs (Ramirez Llodra, 2002).

The reproductive activity of the population was assessed as the percentage of females carrying eggs relative to the total number of females collected (Fransozo \& Mantelatto, 1998; Turra \& Leite, 2000; Martinelli et al., 2002). The monthly occurrence of ovigerous females was assessed through one-way ANOVA followed by a Scheffé's test for multiple comparisons. The Chi-square test $\left(\chi^{2}\right)$ was used to evaluate sex ratio (M:F) and to compare male and female percentages per month. Data was assessed for normality and homogeneity of variance through the Kolmogorov-Smirnov and Levene tests and the mean size of individuals is compared by the Student's $t$-test (Underwood, 1997). The occurrence of juveniles (here defined as individuals of both sexes smaller than the smallest ovigerous female) characterized the recruitment in the population (Turra \& Leite, 2000).

For fecundity analysis, data were analysed using the linear function ( $\mathrm{Y}=\mathrm{a}+\mathrm{bX})$ of egg number (EN) versus shield length (SL). Mean \pm standard deviation (SD) is presented throughout the text.

\section{RESULTS}

A total of 1966 crabs were sampled from which 760 were males $(38.7 \%), 866$ nonovigerous females $(44.0 \%)$ and 340 ovigerous females $(17.3 \%)$. Data was homogeneously distributed (Levene test, $p>0.05$ ). Animal size (minimum, maximum, and mean $\pm \mathrm{SD}$ ) was 2.5, 9.8, and $4.91 \pm 1.48 \mathrm{~mm}$ for males; 2.0 , 5.5 , and $4.27 \pm 0.71 \mathrm{~mm}$ for non-ovigerous females; and 4.0, $8.2 \mathrm{~mm}$, and $4.83 \pm 0.78 \mathrm{~mm}$ for ovigerous females respectively. Males were on average larger than ovigerous females $(t=$ $56.28, p<0.001)$, which in turn were larger than non-ovigerous females $(t=48.78, p<$ $0.05)$.

Figure 1 depicts the yearly size frequency distribution for all hermit crabs sampled during

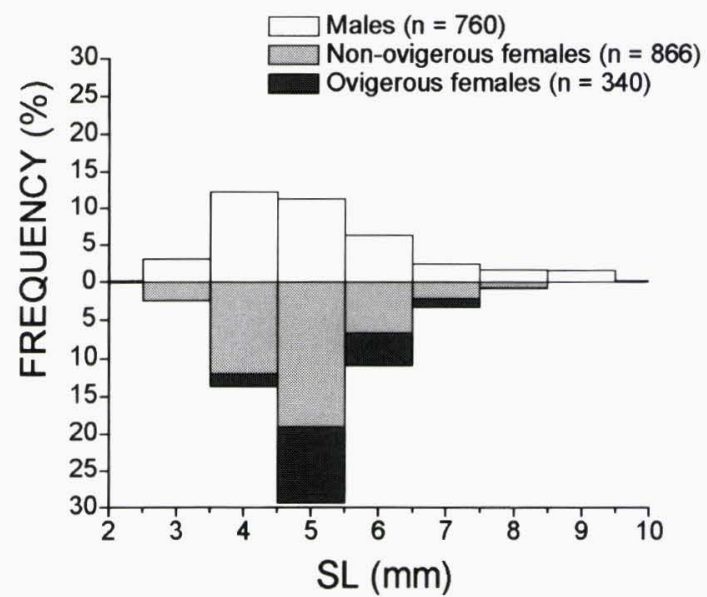

Fig. 1. Calcinus laevimanus. Overall size frequency distribution of individuals sampled at Inhaca Island, southern Mozambique.

the study period. There was a unimodal size distribution with normal distribution slightly skewed to the right for males (KolmogorovSmirnov test, $K S=0.986, p>0.05)$, nonovigerous females $(K S=0.982, p>0.05)$ and ovigerous females $(K S=0.977, p>0.05)$. The size frequency histogram shows a clear prevalence of individuals of both sexes measuring 3.5 to $5.5 \mathrm{~mm}$ SL. The modal size ranged from 3.5 to $4.5 \mathrm{~mm} \mathrm{SL}$ for males and 4.5 to $5.5 \mathrm{~mm}$ $\mathrm{SL}$ for non-ovigerous females and ovigerous females (Fig. 1).

Monthly size frequency distributions for males, non-ovigerous females and ovigerous females are shown in Fig. 2, where major differences can be seen between each demographic category. Males often displayed uni and bimodal distribution, while non-ovigerous and ovigerous females tended to be largely unimodal. Larger males were scarce in the population mainly in March, April, May, July and September.

Overall sex ratio (M:F) was 1: 1.59 in favour of females and significantly differed from the expected 1:1 $\left(\chi^{2}=18.18, p<0.05\right)$. Monthly sex ratios were female-biased during the study period except for the month of January, and during the remainder of the year the percentage of females was significantly 


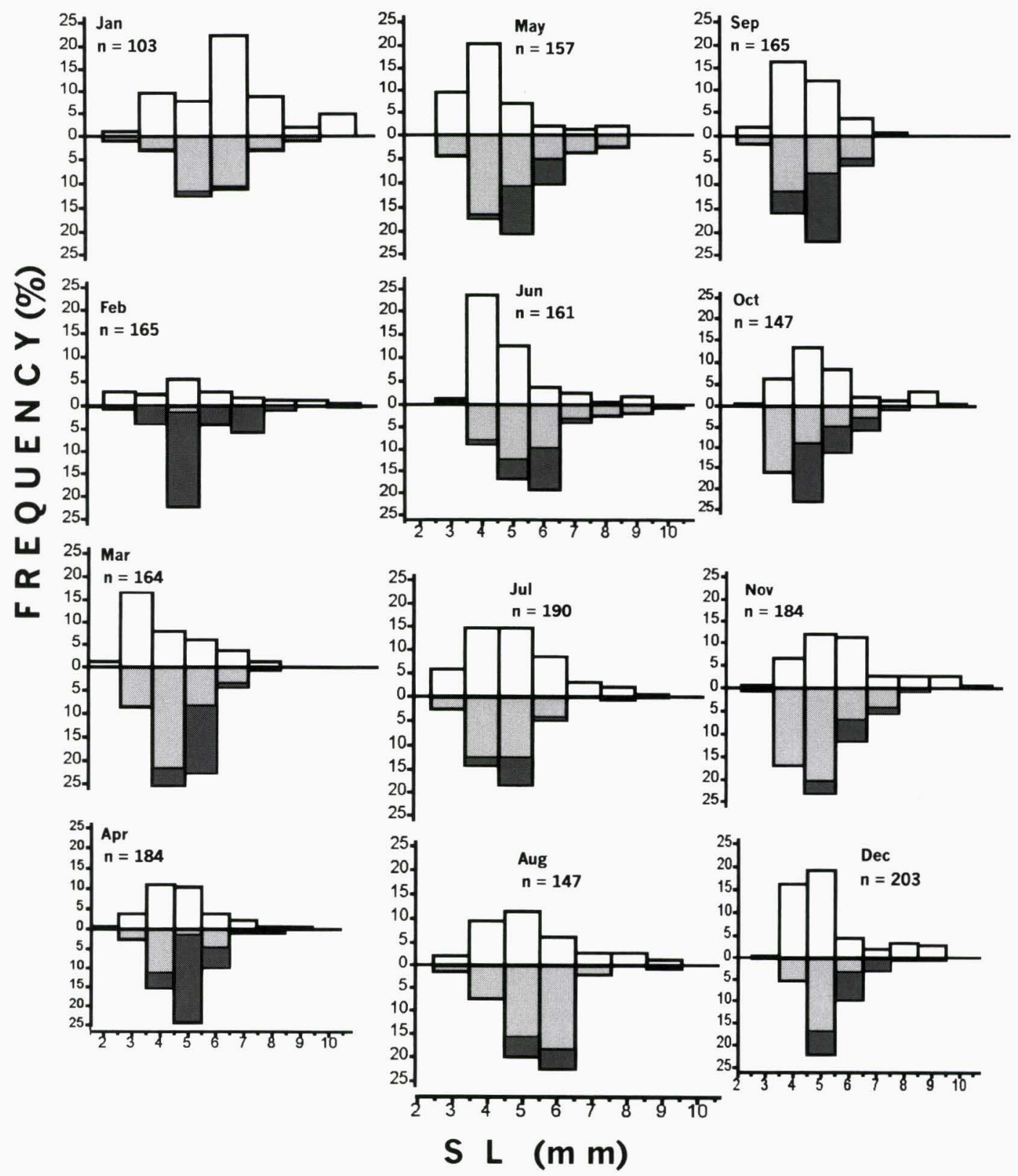

Fig. 2. Calcinus laevimanus. Monthly size frequency distributions of individuals sampled during the study period at Inhaca Island, southern Mozambique. (White bars = males, grey bars = non-ovigerous females, black bars = ovigerous females).

higher than that of males except in June, July and December (Table 1).

Juveniles (all crabs of both sexes $<4.0 \mathrm{~mm}$ $\mathrm{SL}$ ) appeared year-round with higher incidence in March and May (Fig. 3). The lowest num- bers were observed in August and December.

Calcinus laevimanus breeds continuously with peaks in February, April and October. The months of July, August and November, showed the lowest frequency of egg-bearing females 
(Fig. 4).

The number of eggs ranged from 600 (SL $=4.0 \mathrm{~mm})$ to $3000(\mathrm{SL}=8.2 \mathrm{~mm})$, with an average of $1504 \pm 872$ eggs. There was a strong positive relationship between increasing egg number (EN) and increasing shield length (SL) $\left(N=25, r^{2}=0.96394, p<0.001\right)$ (Fig. 5).

\section{DISCUSSION}

The overall size frequency distribution of both sexes was unimodal with males reaching larger sizes than both ovigerous and non-ovigerous females. This condition has been reported in other populations of Calcinus laevimanus in East Africa (Gherardi \& Vannini, 1989) and in other sub-tropical and tropical hermit crabs: Calcinus tibicen (Herbst, 1791) (see Fransozo \& Mantelatto, 1998), Clibanarius antillensis (Stimpson, 1859), Clibanarius sclopetarius (Herbst, 1796), Clibanarius vittatus (Bosc, 1802) (see Turra \& Leite, 2000), and Loxopagurus loxochelis (Moreira, 1901) (see Martinelli et al., 2002). According to Diaz \& Conde (1989), unimodality of size frequency distributions generally characterizes a dynamic equilibrium for a certain population, and the occurrence of slight variations could reflect recruitment pulses, growth or different mortality rates. Moreover, this may indicate that settle-

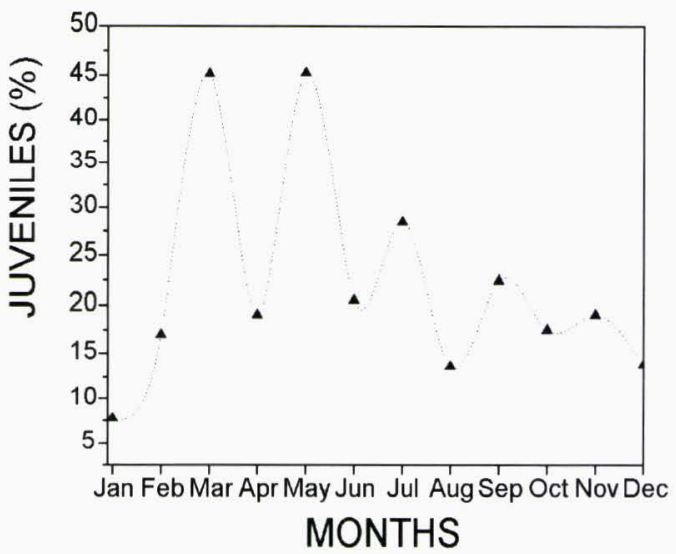

Fig. 3. Calcinus laevimanus. Percentage of juveniles (all crabs $<4.0 \mathrm{~mm} \mathrm{SL}$ ) sampled at Inhaca Island, southern Mozambique.

ment of megalopae occurs in the same habitat as that occupied by the adults.

The lack of larger individuals in the present population of Calcinus laevimanus is also evidenced by its skewed size frequency distribution. Gherardi and colleagues (Gherardi \& Vannini, 1989; Gherardi et al., 1994) found a similar skewed size frequency in their populations of C. laevimanus and Clibanarius laevimanus, respectively. Branco et al (2002) reported the same phenomenon while studying a population of Dardanus insignis (Saussure,

Table 1. Calcinus laevimanus. Total number of individuals, percentage and sex ratio of crabs sampled at Inhaca Island, southern Mozambique from January to December 2003. $(N=$ sample size; ns $=$ not significant, $*$ significant deviation from the 1:1 ratio through the $\chi^{2}$ test, $p<0.05$ ).

\begin{tabular}{|c|c|c|c|c|c|c|}
\hline \multirow[b]{2}{*}{ Month } & \multicolumn{2}{|c|}{ Males } & \multicolumn{2}{|c|}{ Females } & \multirow{2}{*}{$\begin{array}{c}\text { Total } \\
(N)\end{array}$} & \multirow{2}{*}{$\begin{array}{l}\text { Sex ratio } \\
(\mathrm{M}: \mathrm{F})\end{array}$} \\
\hline & $(N)$ & $\%$ & $(N)$ & $\%$ & & \\
\hline January & 58 & 56.31 & 45 & 43.69 & 103 & $1: 0.78 \mathrm{~ns}$ \\
\hline February & 31 & 18.79 & 134 & 81.21 & 165 & $1: 4.32 *$ \\
\hline March & 44 & 26.83 & 120 & 73.17 & 164 & $1: 2.73^{*}$ \\
\hline April & 60 & 32.61 & 124 & 67.39 & 184 & $1: 2.07^{*}$ \\
\hline May & 66 & 42.04 & 91 & 57.96 & 157 & $1: 1.38^{*}$ \\
\hline June & 74 & 45.96 & 87 & 54.04 & 161 & $1: 1.18 \mathrm{~ns}$ \\
\hline July & 94 & 49.47 & 96 & 50.53 & 190 & $1: 1.02 \mathrm{~ns}$ \\
\hline August & 53 & 36.05 & 94 & 63.95 & 147 & $1: 1.78^{*}$ \\
\hline September & 57 & 34.54 & 108 & 65.45 & 165 & $1: 1.89^{*}$ \\
\hline October & 52 & 36.36 & 91 & 63.64 & 143 & $1: 1.75^{*}$ \\
\hline November & 72 & 39.13 & 112 & 60.87 & 184 & $1: 1.56^{*}$ \\
\hline December & 99 & 48.77 & 104 & 51.23 & 203 & $1: 1.05 \mathrm{~ns}$ \\
\hline Total & 760 & 38.66 & 1206 & 61.34 & 1966 & $1: 1.59^{*}$ \\
\hline
\end{tabular}




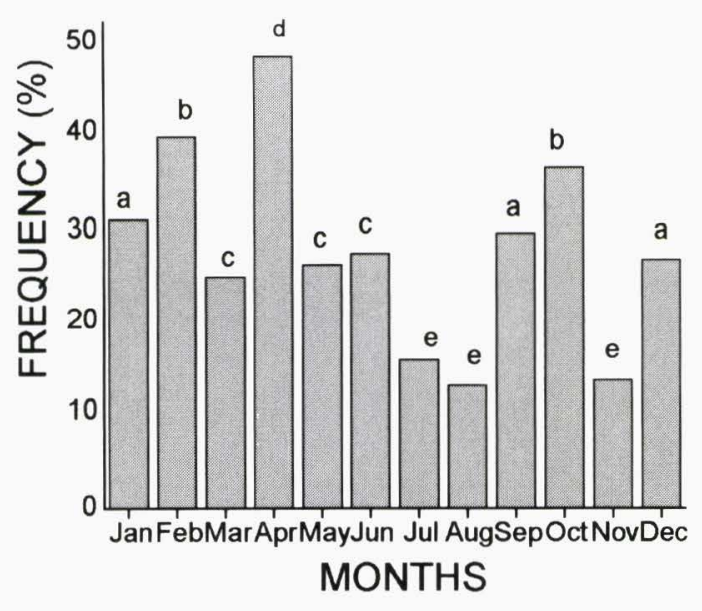

Fig. 4. Calcinus laevimanus. Reproductive activity indicated by the frequency of ovigerous females through the study period at Inhaca Island, southern Mozambique. (Labels indicate significant differences calculated by the Scheffé's test for multiple comparisons).

1858) in Brazil. Right-skewed distributions may be evidence of high mortality rates in certain populations (Underwood, 1997). Branco et al. (2002) suggest that a lack of larger individuals in a population might be physiological or be caused by a deficiency of shells in nature. In fact, large shells are often in limited supply in nature, so that hermit crabs are thought to be under heavy shell limitation (Reddy \& Biseswar, 1993). This situation may be taking place at Inhaca Island because many people collect shells during low tide periods to sell in the markets and hotels for subsistence. This activity may be contributing to the skewness in the size frequency distribution of C. laevimanus.

Calcinus laevimanus at Inhaca Island, Mozambique, is sexually dimorphic with males being generally larger than both ovigerous and non-ovigerous females (Fig. 1). A situation also seen in the Somalian populations of $C$. laevimanus (Gherardi \& Vannini, 1989). Abrams (1988) states that three factors can influence the sexual dimorphism of hermit crabs: 1) the difference in energy available for growth, with males growing more because they do not expend energy in egg production, but use

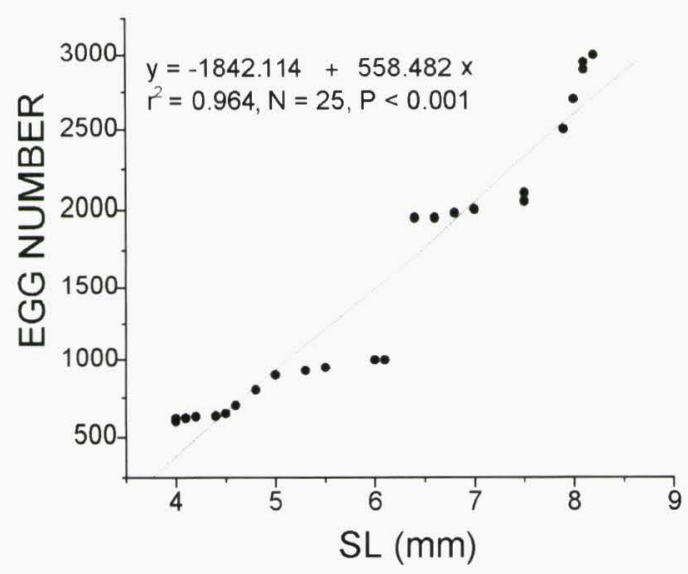

Fig. 5. Calcinus laevimanus. Regression analysis between egg number (EN) and shield length (SL) in females.

their energy for structural metabolism; 2) the larger reproductive effort exhibited by males may be due to their ability to fertilize more than one female; 3 ) males of larger dimensions have a greater chance on obtaining females for copulation as a function of intraspecific fights. Moreover, smaller growth rates of females would be a consequence of the utilization of relatively small shells and of the higher energy allocation to reproduction in relation to males (Asakura, 1992; Bertini \& Fransozo, 2000). We believe that all these factors may influence the size of females in the present population of $C$. laevimanus.

The overall and monthly sex ratios differed from the expected 1:1 proportion (Table 1). Several causes may lead to this discrepancy, such as differences between sexes in longevity and growth rate, differential migration, mortality and sex reversal. Sex reversal (hermaphroditism) has been occasionally reported in hermit crabs (Turra, 2004) but the causes ruling its occurrence are still poorly known (Mantelatto \& Sousa, 2000). According to Werner (1972), sex ratios differing from the 1:1 are widespread among crustaceans. In hermit crabs, females tend to be more abundant than males (AmeyawAkumfi, 1975; Imazu \& Asakura, 1994; Martinelli et al., 2002). Turra \& Leite (2000) state that this may be explained by higher mor- 
tality acting on males or by habitat partitioning, differential feeding restriction or spatial dispersion between sexes. Also important to address is the search for and utilization of shells, which are a limiting resource that may influence the sex ratio, with males being more successful in obtaining adequate shells in relation to females (Asakura, 1992).

In our study juvenile recruitment was continuous. These observations and the maximum size attained by the specimens may support the hypothesis that recruitment may occur in the same habitats from those occupied by adults. Looking at Fig. 3, it can be seen that juveniles recruit mostly during winter (March-June) in the study area. At Inhaca Island, phyto- and zooplankton growth occurs from September to November and a major period of plankton abundance occurs by March due to nutrient accumulation along the winter season (Paula et al., 1998). These observations may lead us to suggest that juvenile recruitment is synchronized with the abundance of food resources, which are crucial for larval and juvenile growth.

Hermit crabs may display continuous (with or without peaks) or seasonal reproductive patterns (Bertness, 1981; Tunberg et al., 1994; Manjón-Cabeza \& Garcia Raso, 1998) regardless of the taxonomic group. As noted by Sastry (1983), populations of a given species at different latitudes subjected to particular environmental conditions may display different reproductive patterns. Continuous or wide reproductive periods shown by hermit crabs may be a result of multiple spawnings or asynchrony in reproduction.

Ovigerous females of $C$. laevimanus were found year-round in the study area but with peaks in February, April and October, suggesting a continuous reproductive pattern (Fig. 4). A similar pattern was found in Paguristes tortugae studied by Mantelatto \& Sousa (2000) and Clibanarius antillensis studied by Turra \& Leite (2000). Continuous reproduction is important for the determination of several characteristics of a population such as continuous larval supply and juvenile recruitment, which are important mechanisms to stabilize a population. Discontinuous or prolonged reproduction is also common among subtropical and tropical hermit crabs. According to Turra \& Leite (2000), any hypothesis to explain the occurrence of populations with seasonal reproductive patterns in the tropics and with continuous patterns in temperate regions may be based on the evolutionary histories of population although local factors such as competition and shell use, should also be considered when assessing the reproductive traits of a species or population.

Fecundity (number of eggs per egg clutch) increased in proportion with female shield length (Fig. 5). This was to be expected as the egg number of most hermit crabs increases in parallel with female size (Mantelatto \& Garcia, 1999; Turra \& Leite, 2001b; Mantelatto et al., 2002; Litulo, 2004; Macpherson \& Raventos, 2004). Small variations in the number of eggs were observed within the same size classes. According to Sastry (1983) and Mantelatto et al. (2002), this can be related to accidental loss of eggs, incomplete fertilisation or multiple spawnings. Multiple spawnings (here defined as females spawning several times after each release of previous larvae) are generally characteristic in tropical hermit crabs due to small variations in environmental parameters, which are very important for egg and larval development (Sastry, 1983). The large jump (doubling) in egg number observed at about $6 \mathrm{~mm}$ (SL) (Fig. 5) could represent the difference between first mating (primaparous) and already mated (multiparous) females, or more likely is a consequence of a gastropod host shell switch to a larger species providing more egg space (Mantelatto \& Garcia, 1999).

The characterization of populations in natural habitats is important to understand their life cycle and ecological stability. This can be accomplished by describing patterns of distribution, density, dispersion, sex ratio and breeding periods that can be compared to other populations of the same species, genus or other taxonomic level. Such comparisons are an important strategy to verify differences among populations and to understand the environmen- 
tal constraints that are shaping the structure of these populations (Branco et al., 2002). This data on Calcinus laevimanus is a starting point to gaining this understanding for tropical hermit crabs, especially in the poorly studied region of East Africa.

Acknowledgements. - We thank the Marine Biological Station of Inhaca Island (EBMI) for logistical support, and WIOMSA (Western Indian Ocean Marine Science Association) for financial support. CCT wishes to acknowledge the support of Rafael Lemaitre and previous IZ Department chairs at NMNH, Smithsonian Institution, for access to resources. This manuscript was substantially improved by the comments of two anonymous referees.

\section{LITERATURE CITED}

Abrams, P., 1988. Sexual differences in resource use in hermit crabs; consequences and causes. In: G. Chelazzi \& M. Vannini, (eds.), Behavioural Adaptation to the Intertidal Life, Plenum, New York, pp. 283-296.

Ameyaw-Akumfi, C., 1975. The breeding biology of two sympatric species of tropical intertidal hermit crabs, Clibanarius chapini and $C$. senegalensis. Marine Biology, 29: 15-28.

Asakura, A., 1992. Population ecology of the sanddwelling hermit crab Diogenes nitidimanus Terao. 5. Ecological implications in the patterns of moulting. Journal of Crustacean Biology, 12: 537-545.

Asakura, A., \& Kikuchi, T., 1984. Population ecology of the sand dwelling hermit crab, Diogenes nitidimanus Terao 2. Migration and life history. Publications of the Amakusa Marine Biology Laboratory, 7: 109-123.

Barnes, D. K. A., 1997. Ecology of tropical hermit crabs at Quirimba Island, Mozambique: distribution, abundance and activity. Marine Ecology Progress Series, 154: 133-142.

Barnes, D. K. A., 1999. Ecology of tropical hermit crabs at Quirimba Island, Mozambique: Shell characteristics and utilization. Marine Ecology Progress Series, 183: 241-251.

Bertini, G., \& Fransozo, A., 2000. Population dynamics of Petrochirus diogenes (Crustacea, Anomura, Diogenidae) in the Ubatuba region, São Paulo, Brazil. Crustacean Issues, 12: $221-$ 241.

Bertini, G., \& Fransozo, A., 2002. Breeding season of the hermit crab Petrochirus diogenes (Anomura: Diogenidae) in the north coast of São Paulo State, Brazil. In: E. Escobar-Briones \& F. Alvarez, (eds.), Modern Approaches to the Study of Crustacea, Kluwer Academic Publishers, The Netherlands, pp. 145-150.

Bertness, M. D., 1981. Seasonality in tropical hermit crab reproduction in the bay of Panama. Biotropica, 13: 292-300.

Branco, J. O., Turra, A., \& Souto, F. X., 2002. Population biology and growth of the hermit crab Dardanus insignis at Armação do Itapocoroy, southern Brazil. Journal of the Marine Biological Association of the United Kingdom, 82: 597603.

Diaz, H., \& Conde, J. E., 1989. Population dynamics and life history of the mangrove crab Aratus pisonii (Brachyura, Grapsidae) in a marine environment. Bulletin of Marine Science, 45: 148-163.

Emmerson, W. D., \& Alexander, M. D., 1986. Shell utilization and morphometrics of the hermit crab Diogenes brevirostris Stimpson. South African Journal of Zoology, 21: 211-216.

Fransozo, A., \& Mantelatto, F. L. M., 1998. Population structure and reproductive period of the tropical hermit crab Calcinus tibicen (Decapoda: Diogenidae) in the region of Ubatuba, São Paulo, Brazil. Journal of Crustacean Biology, 18: 738-745.

Gherardi, F., \& Vannini, M., 1989. Field observations on activity and clustering in two intertidal hermit crabs, Clibanarius virescens and Calcinus laevimanus (Decapoda, Anomura). Marine Behaviour and Physiology, 14: 145-159.

Gherardi, F., Zatteri, F., \& Vannini, M., 1994. Hermit crabs in a mangrove swamp: the structure of Clibanarius laevimanus clusters. Marine Biology, 121:41-52.

Guerreiro, J., Freitas, S., Pereira, P., Paula, J., \& Macia, A., 1996. Sediment macrobenthos of mangrove flats at Inhaca Island, Mozambique. Cahiers de Biologie Marine, 37: 309-327.

Imazu, M., \& Asakura, A., 1994. Distribution, reproduction and shell utilization patterns in three species of intertidal hermit crabs on a rocky shore on the Pacific coast of Japan. Journal of Experimental Marine Biology and Ecology, 184: 42-65.

Kamalaveni, S., 1949. On the ovaries, copulation and egg-formation in the hermit crab, Clibanarius olivaceus Henderson (Crustacea, Decapoda). Journal of the Zoological Society of India, 1: 120-128.

Lancaster, I., 1988. Pagurus bernhardus (L). - An introduction to the life history of hermit crabs. Field Studies, 7: 189-238. 
Litulo, C., 2004. Fecundity and breeding biology of the hermit crab Diogenes brevirostris (Stimpson, 1858) (Anomura: Diogenidae) from southern Mozambique. Invertebrate Reproduction and Development, 46: 41-46.

Litulo, C., 2005. Population structure and reproduction of the hermit crab Dardanus deformis (Anomura: Diogenidae) in the Indian Ocean. Journal of the Marine Biological Association of the United Kingdom, 85: 883887.

Litulo, C., \& Tudge, C., 2005. Population structure and breeding season of the hermit crab Diogenes brevirostris Stimpson, 1858 (Decapoda, Anomura, Diogenidae) from southern Mozambique. Journal of Natural History, 39: 2887-2899.

Macpherson, E., \& Raventos, N., 2004. Population structure and reproduction of three sympatric species of hermit crabs in the north-western Mediterranean. Journal of the Marine Biological Association of the United Kingdom, 84: 371376.

Manjón-Cabeza, M. E., \& Garcia Raso, J. E., 1994. Estructura de una población del cangrejo ermitaño Cestopagurus timidus (Crustacea, Decapoda, Anomura) de fondos de Posidonia oceanica del SE de España. Cahiers de Biologie Marine, 35: 225-236.

Manjón-Cabeza, M. E., \& Garcia Raso, J. E., 1995. Study of Calcinus tubularis (Crustacea, Diogenidae) from a shallow Posidonia oceanica meadow. Cahiers de Biologie Marine, 36: $277-$ 284.

Manjón-Cabeza, M. E., \& Garcia Raso, J. E., 1998. Population structure and growth of the hermit crab Diogenes pugilator (Decapoda: Anomura: Diogenidae) from the Northwestern Atlantic. Journal of Crustacean Biology, 18: 753-762.

Mantelatto, F. L. M., \& Garcia, R. B., 1999. Reproductive potential of the hermit crab Calcinus tibicen (Anomura) from Ubatuba, São Paulo, Brazil. Journal of Crustacean Biology, 19: 268-275.

Mantelatto, F. L. M., \& Sousa, L. M., 2000. Population dynamics of the hermit crab Paguristes tortugae Schmitt, 1933 (Anomura, Diogenidae) from Anchieta Island, Ubatuba, Brazil. Nauplius, 8: 185-193.

Mantelatto, F. L. M., Alarcon, V. F., \& Garcia, R. B., 2002. Egg production strategies of the tropical hermit crab Paguristes tortugae from Brazil. Journal of Crustacean Biology, 22: 390-397.

Martinelli, J. M., Mantelatto, F. L. M., \& Fransozo, A., 2002. Population structure and breeding season of the South Atlantic hermit crab Loxopagurus loxochelis (Anomura, Diogenidae) from the Ubatuba region, Brazil. Crustaceana,
75: 791-802.

Paula, J., Pinto, I., Guambe, I., Monteiro, S., Gove, D., \& Guerreiro, J., 1998. Seasonal cycles of planktonic communities at Inhaca Island, southern Mozambique. Journal of Plankton Research, 20: 2165-2178.

Ramirez Llodra, E., 2002. Fecundity and life-history strategies in marine invertebrates. Advances in Marine Biology, 43: 87-170.

Reddy, T., \& Biseswar, R., 1993. Patterns of shell utilization in two sympatric species of hermit crabs from the Natal coast (Decapoda, Anomura, Diogenidae). Crustaceana, 56: 13-24.

Sastry, A. N., 1983. Ecological aspects of reproduction. In: F. Vernberg \& W. Vernberg, (eds.), The Biology of Crustacea, 8 . Environmental adaptations, Academic Press, New York, pp. 179-269.

Tudge, C. C., 1995a. Hermit Crabs of the Great Barrier Reef and Coastal Queensland. 40 pp. School of Marine Science, University of Queensland, Australia \& Backhuys Publishers, Leiden.

Tudge, C. C., 1995b. Ultrastructure and phylogeny of the spermatozoa of the infraorders Thalassinidea and Anomura (Decapoda, Crustacea). In: B.G.M. Jamieson, J. Ausio, \& J.-L. Justine, (eds.), Advances in Spermatozoal Phylogeny and Taxonomy. Mémoires du Muséum national d'Histoire naturelle (Paris), 166: 251-263.

Tudge, C. C., 1995c. The Ultrastructure and Phylogeny of Anomuran Crab Spermatozoa. 346 pp. Ph.D. Thesis, Zoology Department, University of Queensland, Brisbane, Australia.

Tunberg, B., Nelson, W. G., \& Smith, G., 1994. Population ecology of Pagurus maclaughlinae Garcia-Gomez (Decapoda: Anomura: Paguridae) in the Indian River Lagoon, Florida. Journal of Crustacean Biology, 14: 686-699.

Turra, A., \& Leite, F. P. P., 2000. Population biology and growth of three sympatric species of intertidal hermit crabs in south-eastern Brazil. Journal of the Marine Biological Association of the United Kingdom, 80: 1061-1969.

Turra, A., \& Leite, F. P. P., 2001a. Shell utilization patterns of a tropical rocky intertidal hermit crab assemblage: I. The case of Grande beach. Journal of Crustacean Biology, 21: 393-406.

Turra, A., \& Leite, F. P. P., 2001b. Fecundity of three sympatric populations of hermit crabs (Decapoda, Anomura, Diogenidae). Crustaceana, 74: 1019-1027.

Turra, A., 2005. Intersexuality in hermit crabs: role and fate of gonopores in intersex individuals. Journal of the Marine Biological Association of the United Kingdom, 84: 757-759.

Underwood, A. J,. 1997. Experiments in Ecology: their Logical Design and Interpretation Using 
Analysis of Variance. 504 pp. Cambridge University Press, Cambridge.

Wada, S., Goshima, S., \& Nakao, S., 1995.

Reproductive biology of the hermit crab Pagurus middendorffii Brandt (Decapoda: Anomura: Diogenidae). Crustacean Research, 24: 23-32.

Werner, A. M., 1972. Sex ratio as a function of size in marine Crustacea. American Naturalist, 106: $321-350$

Addresses: *CL, DA, Departamento de
Ciências Biológicas, Faculdade de Ciências, Universidade Eduardo Mondlane, Caixa Postal 257, Maputo, Mozambique; e-mail: (CL) Litos@uem. mz. CCT, Invertebrate Zoology, MRC 163, National Museum of Natural History, Smithsonian Institution, Washington, DC 20013-7012, U.S.A., and Department of Biology, American University, Washington, D.C. 20016-8007, U.S.A.; e-mail: tudgec@si.edu

*Author for correspondence 